\title{
Investigating the Relationship Between Board of Directors and Corporate Financial in Jordan
}

\author{
Mohammad Tayseer Alshaboul, Mohammad Ahmad Abu Zraiq \\ Faculty of Business \& Information Science, UCSI University, Kuala Lumpur, Malaysia \\ Email address: \\ Shboul1994@gmail.com (M. T. Alshaboul), Mabuzreiq@yahoo.com (M. A. A. Zraiq) \\ To cite this article: \\ Mohammad Tayseer Alshaboul, Mohammad Ahmad Abu Zraiq. Investigating the Relationship Between Board of Directors and Corporate \\ Financial in Jordan. Journal of Finance and Accounting. Vol. 8, No. 2, 2020, pp. 59-63. doi: 10.11648/j.jfa.20200802.11
}

Received: February 24, 2020; Accepted: March 9, 2020; Published: April 1, 2020

\begin{abstract}
This study provides clear evidences indication on the association of the board of directors and the corporate financial performance. This study investigates the relationship between board of directors' mechanism namely (board size, board independence, board meeting frequency, and CEO duality) and corporate financial performance among industrial Jordanian listed corporations on Amman stock exchange (ASE) for the period 2016-2017. Corporate financial performance is measure by Return on Asset (ROA) and Return on Equity (ROE). This study contributes to the existing literature It adds values to the existing literature by providing extensive insights of the role of the board of director and corporate financial performance. The multiple regression analysis used to test the 4 hypotheses. Corporations listed in ASE are the subjects of this study for the years 2016 and 2017. The result of the independent variable namely board size, board independence, board meeting frequency, and CEO duality affects the Return on Asset (ROA) significantly. However, there is only one independent variable namely CEO duality that is insignificantly related to Return on Asset (ROA). Furthermore, the result of multiple regression analysis indicates that there is a significant relationship between highly linked to board size, board independence, and board meeting frequency and Return on Equity (ROE). On other hand contrary, the regression analysis shows the CEO Duality to be insignificantly related to Return on Equity (ROE).
\end{abstract}

Keywords: Corporate Financial Performance, Board of Directors, Corporate Governance, Jordan

\section{Introduction}

Advantageous corporate governance is primary for the development of economic lead up to by the private strip and for enhance of the public felicity [1]. The demand for corporate governance may have arisen from the dispute among the management of the corporation and the external shareholder. Corporate Governance Code was issued by Jordanian government in 2009 by Jordan Securities Commission, and since 2009 Jordanian corporations need to adhere to the prerequisites of the Code [2].

Corporate governance is important because it's lead to corporation reforms [3]. The scholar mentioned the effective corporate governance enhance the financial performance and increase profit. Many researches has been done to investigate the effect of board of director on financial performance in the developed countries such as china [4], Malaysia [5], United Kingdom (UK) [6], Romania [7].

Board of Directors in Jordan are described as corporate gadgets with poor disciplinary capacity [9]. Makhlouf et al. 2017 discovered that in Jordan, $23 \%$ of the seats in the board are occupied by family members who own $25 \%$ stake in the company. This is in contrast to the 2009 Corporate Governance Code published by Amman Stock Exchange because they were ignoring minority shareholders [9]. Also, Jordanian corporations are not aware of some elements of board governance, such as the committee's formation, CEO duality, and independent directors' selection [10]. Poor monitoring from the board leads to poor implementation of the board governance mechanism. [11]. This impact strategic decision-making, subsequently impacting corporate financial performance negatively [12]. The shareholders eventually comprehend that the board of directors should play an active function to attract better investment capital to provide better shareholder returns subsequently enhancing corporate financial performance [13].

Moreover, the previous study has been conducted such as Makhlouf [9] and Saidat [14] relying on data for period from 
2009 to 2015 for registered corporate in Amman Stock Exchange. which may affect the finding. Due to the early stage of implementation and comprehend of corporate governance in Jordan. Therefore, this paper aims to investigate the impact of Board of Director on Financial Performance.

\section{Literature Review and Hypothesis Development}

The board of directors represents the top authority of the corporation in supervising the corporation's high-level management [15]. Previous studies have provided evidence that the board of directors enhance corporate financial performance [16].

\subsection{Board Size}

The most vital governance mechanisms are board size as it shows the partnership of a board in corporate affairs and performance. The empirical evidence showed that board size was essentially and well-linked to corporate financial performance [17]. The board size significantly and positively related with the financial performance [18]. The financial performance of corporation is better influenced by a larger size of the board [14]. The board size impact the financial performance positively (Kiel and Nicholson 2003). Nevertheless, the weaknesses of the board of directors' role in Jordanian corporations in the monitoring function. They contributed the finding to the engagement of beyond fourteen members on the board [19]. Based on the above discussion, the following hypothesis is proposed to be tested:

H1. There is a relationship between board size and corporate financial performance.

\subsection{Board Independence}

Independent board members are described as members of the board, who are unrelated either to the corporation or to the top management [20]. Jensen and Meckling (1976) [21] asserted that boards consists of external or non-executive directors are most likely to assist in overcoming agency problems via ensuring effective control as well as monitoring of management's opportunistic behaviour. This independence is considered as a crucial feature of the board which determines its effectiveness in the control and monitoring of managerial activities [22].

Particular elements like corporate acquisition, financial reporting and performance are better observed and controlled by independent external directors [23]. A strong relation between independent directors and financial performance by analysed 103 corporate listed on ASE [14]. the independent directors affect the financial performance positively [9]. Hence, the hypothesis is phrased as follows:

H2. There is a relationship between board independence and corporate financial performance.

\subsection{Board Meeting Frequency}

The Jordan Corporate Governance Code (2009) [20] requires that the board of directors to conduct not less than six meetings annually. Board of directors that conduct regular meetings tend to perform better in accordance to the shareholders' interests as more time can be used to observe and resolve matters pertaining to management earnings, contention, and management observation.

The board of directors should hold regular meetings so that they can assess any corporate situation, any issues that arise, or new suggestions [9], board meeting frequency is a good influence on financial performance [24]. A lower board meeting would improve financial performance [25]. On other hand, the board meeting frequency is just one of the monitoring devices to enhance the financial performance [26]. Thus, the hypothesis is formulated as follows:

H3. There is a relationship between board meeting frequency and corporate financial performance.

\subsection{CEO Duality}

When a person holds the position of the CEO and the board chairman at the same time, it creates duality [22]. The concentration of power in one person may lead to decisions being made in their own interests, instead of taking the other stakeholders into account [21].

CEO duality had an important and positive impact with financial performance [27]. When two roles are separated, the corporation always shows better financial returns as compared to when the duality exist [28]. The result of Issarawornrawanich in 2015, showed that, the CEO duality has an adverse impact on financial performance [15]. As mentioned on the Jordanian Corporate Governance Code (2009), the rules ban the merging of the board chairperson role with any other executive role within the corporation [20]. Hence, the hypothesis is phrased as follows:

H4. There is a relationship between CEO duality and corporate financial performance

\section{Measurement of Variables}

Table 1. Measurement of variables.

\begin{tabular}{ll}
\hline Variables & Measurement \\
\hline Dependent variable & \\
Return on Asset $(R O A)$ & calculated by the proportion of total earnings to total assets \\
Return on Equity $(R O E)$ & Percentage of shareholders' equity over total earnings. \\
Independent variable & \\
Board size (BISZ) & Total members of the board. \\
\hline
\end{tabular}




\begin{tabular}{ll}
\hline Variables & Measurement \\
\hline Board independence (BIND) & The percentage of independent directors in the board. \\
Board meeting frequency (BMET) & Number of board meetings during the year \\
CEO duality (CEO) & Coded " 1 " if Chairman also holds the position of CEO and " 0 " otherwise \\
\hline
\end{tabular}

\section{Research Methodology}

The Jordanian listed corporations in the Amman Stock Exchange consist of three sectors which are industrial, financial, and services sector. This study will focus on the listed industrial corporations and its present 46 corporations. The total registered industrial corporations in the Amman Stock Exchange are 46. Secondary data for this study will be derived from the annual report for the industrial corporations registered on ASE for the year 2016-2017.

Table 2. Analysis of sample.

\begin{tabular}{lll}
\hline Year & No. of the corporate & Availability \\
\hline 2016 & 46 & 46 \\
2017 & 46 & 46 \\
Total & 92 & 92 \\
\hline
\end{tabular}

\subsection{Data Analysis}

In this section, the finding of the study established on the research objectives and the hypotheses were highlighted.

\subsection{Descriptive Analysis}

The descriptive analysis serves to calculate the average, range (minimum and maximum) and standard deviation for every variable of the study.

Table 3. Descriptive analysis.

\begin{tabular}{|c|c|c|c|c|c|}
\hline \multicolumn{6}{|l|}{ Descriptive Statistics } \\
\hline & $\mathbf{N}$ & Minimum & Maximum & Mean & Std. Deviation \\
\hline Board Size & 92 & 5 & 15 & 8.13 & 2.512 \\
\hline Board Independence & 92 & 0 & 5 & 2.55 & .942 \\
\hline Board Meeting Frequency & 92 & 6 & 12 & 7.33 & 1.541 \\
\hline CEO Duality & 92 & 0 & 1 & .25 & .435 \\
\hline ROA & 92 & -17.9000 & 29.4600 & 5.7800 & 33.48858 \\
\hline ROE & 92 & -36.7000 & 115.0800 & 9.970435 & 17.0321585 \\
\hline
\end{tabular}

The Table 3 shows that the lowest value of the board size is 5 , while the maximum value is 15 , the mean value is 8.13 and the standard deviation is at 2.512 . Hence, this finding is close to the finding of [9].

The Descriptive Statistics reported the minimum value of Board Independence of 0 and the maximum is 5 . On other side, the value of mean for Board Independence is 2.55 and the standard deviation is 0.942 . Furthermore, this result is in consistent with the result of [25]. In addition, the result presented that the minimum value for Board Meeting Frequency is 6 and the maximum value is 12 . Then the result showed the mean is 7.33 and the standard deviation is 1.541 . Moreover, this result is close to the finding of [25].

The descriptive statistics reported that the majority of industrial corporations registered in ASE comply with the
Jordanian corporate governance code for the segregation of the CEO and Chairman. The result reported the minimum statistics to be 0 and the maximum is 1 .

Therefore, the result shows the standard deviation is 0.435 and the mean statistics is 0.25 . Apparently, the descriptive statistics reported similar result to the result of [9]. Generally, the maximum value for ROA of industrial corporate listed in ASE is -17.90 , the minimum value is 29.46 . On other hand, the mean value is 5.78 and standard deviation is 33.48. In addition, this finding is relative to the result of [16]. As reported in the descriptive statistics, the minimum statistics of ROE is -36.70 and the maximum statistics is 115.08 Moreover, the descriptive statistics shows the mean value of $\mathrm{ROE}$ is 9.97 and the standard deviation is 17.03 . This finding is close to the finding of [16].

Table 4. Correlations matrix.

\begin{tabular}{|c|c|c|c|c|c|c|}
\hline & Board size & Board independence & Board meeting frequency & CEO duality & ROA & ROE \\
\hline Board size & 1 & & & & & \\
\hline Board independence & $.583 * *$ & 1 & & & & \\
\hline Board meeting frequency & .086 & .056 & 1 & & & \\
\hline CEO duality & -.032 & .046 & -.044 & 1 & & \\
\hline ROA & $.595 * *$ & $.529 * *$ & $.421 * *$ & -.103 & 1 & \\
\hline ROE & $.619 * *$ & $.527 * *$ & $.388 * *$ & -.117 & $.958 *$ & 1 \\
\hline
\end{tabular}

**. Correlation is significant at the 0.01 level 


\subsection{Multiple Regression Analysis}

Two models were used to examine the relationship between Board of director and financial performance.

Model 1- Return on Assets

ROA: $\beta 0+\beta 1$ BSIZit $+\beta 2$ BINDit $+\beta 3$ BMETit + $\beta 4 \mathrm{CEO}$ it + cit
Model 2- Return on Equity

ROE: $\beta 0+\beta 1$ BSIZit $+\beta 2$ BINDit $+\beta 3$ BMETit + $\beta 4$ CEOit+ $\varepsilon$ it

The hypothesis is significance between $(0.01,0.05$ and 0.1$)$ for quality assurance.

Table 5. Models of study.

\begin{tabular}{|c|c|c|c|c|c|c|}
\hline \multicolumn{7}{|c|}{ Models of study } \\
\hline & \multicolumn{3}{|c|}{ ROA (Model) 1} & \multicolumn{3}{|c|}{ ROE (Model) 2} \\
\hline Variables & Beta & $\mathrm{t}$ & Sig. & Beta & $\mathrm{t}$ & Sig. \\
\hline (Constants) & & -6.793 & 0.000 & & -6.574 & 0.000 \\
\hline Board Size & 0.397 & 4.331 & 0.000 & 0.437 & 4.479 & 0.000 \\
\hline Board Independence & 0.280 & 3.057 & 0.003 & 0.259 & 2.815 & 0.006 \\
\hline Board Meeting Frequency & 0.367 & 4.930 & 0.000 & 0.331 & 4.430 & 0.000 \\
\hline CEO Duality & -0.087 & -1.172 & 0.245 & -0.100 & -1.334 & 0.183 \\
\hline
\end{tabular}

The result of the independent variable namely board size, board independence and board meeting frequency affects the Return on Asset (ROA) significantly. However, there is only one independent variable namely $\mathrm{CEO}$ duality that is insignificantly related to Return on Asset (ROA).

Furthermore, the result indicates that there is a significant relationship between highly linked to board size, board independence, and board meeting frequency and Return on Equity (ROE). On other hand, the regression analysis shows the CEO Duality insignificantly related to Return on Equity (ROE).

\section{Conclusion}

The investigation in study explores the financial performance of Jordanian listed corporation, particularly the industrial corporations over the year 2016-2017. Future studies may investigate the same period but in another sector such as services or financial also they may consider the educational backgrounds of CEO and board members. Hence, the validation of the conclusion might not hold for other sector such as services or financial. Thus, the generalization of findings is only limited to the Jordanian listed industrial corporation.

This study recommends that, the board size should be between 9 and 15 members because small boards are more susceptible to failure in improving corporate financial performance while the larger board size had a positive impact to improve corporate financial performance. Therefore, higher number of boards of director may increase the number of potential solutions, increase the range of opinion, provide an increased pool of experience, and be more capable of monitoring the job of top management. Moreover, the relationship between board independence and corporate financial performance is positive and significant. The financial performance of corporation will improve if the independent member above $30 \%$, also financial reporting is better to observed and controlled by independent external directors. Additionally, the board meeting frequency have a positive relationship with corporate financial performance, when the board have at minimum 6 meeting during the year to discuss the situation of the corporate, leads to improve the corporate financial performance.

This study contributes to the existing literature It adds values to the existing literature by providing extensive insights of the role of the board of director and corporate financial performance. Corporations listed in ASE are the subjects of this study. The result of the independent variable affects the ROA (refer to model 1) significantly. However, there is only one independent variable namely CEO duality that is insignificantly related to ROA. Furthermore, the result of second model ROE indicates that there is a significant relationship between highly linked to board size, board independence, and board meeting frequency and ROE. On other hand contrary, the regression analysis shows the CEO Duality to be insignificantly related to ROE.

\section{References}

[1] OECD (2015), G20/OECD Principles of Corporate Governance, OECD Publishing, Paris. http://dx.doi.org/10.1787/9789264236882-en.

[2] Alkhatib, K., \& Al Bzour, A. E. (2011). Predicting corporate bankruptcy of Jordanian listed companies: Using Altman and Kida models. International Journal of Business and Management, 6 (3), 208.

[3] Akbar, A. (2015). The role of corporate governance mechanism in optimizing firm performance: A conceptual model for corporate sector of Pakistan. Journal of Asian Business Strategy, 5 (6), 109-115.

[4] Sasidharan, A., \& Varghese, G. (2019). Impact of Ownership Structure and Board Characteristics on Firm Value: Evidence from China and India.

[5] Yusoff, W. F. W., \& Alhaji, I. A. (2012). Corporate governance and firm performance of listed companies in Malaysia. Trends and Development in Management Studies, 1 (1), 43-65.

[6] El-Faitouri, R. (2014). Board of Directors and Tobin's Q: Evidence from UK Firms. Journal of Finance and Accounting, 2 (4), 82-99. 
[7] Achim, M.-V., Borlea, S.-N., \& Mare, C. (2016). Corporate Governance And Business Performance: Evidence For The Romanian Economy. Journal of Business Economics and Management, 17 (3), 458-474.

[8] Alwshah, K. A. A. M. (2009). The Impact Of Corporate Governance And Ownership Structure On Performance And Financial Decisions Of Firms: Evidence From Jordan. ( $\mathrm{PhD}$ thesis), University of Hull.

[9] Makhlouf, M. H., Laili, N. H., Ramli, N. A., \& Basah, M. Y. (2017). Board of directors' effectiveness and firm performance: Evidence from Jordan. Research Journal of Finance and Accounting, 8 (18), 23-34.

[10] Al-Kassar, T. A., \& Al-Nidawiy, M. A. (2014). The Role Of Corporate Governance And Its Impact On The Share Price Of Industrial Corporations Listed On The Amman Stock Exchange. European Journal of Accounting Auditing and Finance Research, 2 (6), 106- 123.

[11] Matar, M., \& Nauimat, Z. (2014). The Response of The Boards of Directors In the Distressed Jordanian Public Shareholding Companies to The Risk And Repercussions of The Global Financial Crisis. Jordan Journal of Business Administration, 10 (1).

[12] Arora, A., \& Sharma, C. (2016). Corporate Governance And Firm Performance In Developing Countries: Evidence From India. Corporate Governance, 16 (2), 420-436.

[13] Marashdeh, Z. M. S. (2014). The Effect of Corporate Governance on Firm Performance in Jordan. (Ph.D thesis), University of Central Lancashire.

[14] Saidat, Z., Silva, M., \& Seaman, C. (2019). The relationship between corporate governance and financial performance. Journal of Family Business Management.

[15] Issarawornrawanich, Panya (2015). The Association between Board of Directors' Characteristics and Firm Performance: Empirical Evidence from Emerging Market of Thailand. Journal of Applied Business and Economics, 17 (1): 54-65.

[16] Alabdullah, T. T. Y., Yahya, S., \& Ramayah, T. (2014) Corporate governance mechanisms and Jordanian companies' financial performance. Asian Social Science, 10 (22), 247.

[17] Alaryan, L. A. (2017). Exploring the Role of Board Characteristics on Enhancing Financial Performance of Jordanian Listed Companies. International Journal of Economics and Finance, 9 (7), 99-105.
[18] Shrivastav, S. M., \& Kalsie, A. (2016). The Relationship Between CEO Duality and Firm Performance: An Analysis Using Panel Data Approach. IUP Journal of Corporate Governance, 15 (2).

[19] Abed, S., Al-Badainah, J., \& Serdaneh, J. A. (2012). The Level of Conservatism in Accounting Policies and Its Effect on Earnings Management. International Journal of Economics and Finance, 4 (6), p78.

[20] Amman Stock Exchange. (2017). Amman Stock Exchange. Retrieved from: https://www.ase.com.jo/en/unlistedsecurities-otc/equities-otc.

[21] Jensen, M. C., \& Meckling, W. H. (1976). Theory of the firm: Managerial behavior, agency costs and ownership structure. Journal of financial economics, 3 (4), 305-360.

[22] Fama, E., \& Jensen, M. (1983). Agency problems and residual claims. The Journal of Law and Economics, 26 (2), 327-349.

[23] Iskandar, T. M., Rahmat, M. M., Noor, N. M., Saleh, N. M., \& Ali, M. J. (2011). Corporate governance and going concern problems: evidence from Malaysia. International Journal of Corporate Governance, 2 (2), 119-139.

[24] Tong, S., Junarsin, E., \& Davidson III, W. N. (2013). A comparison of Chinese state-owned enterprise firm's boards and private firm's boards. In 23rd International Business Research Conference, Melbourne, Australia.

[25] Qadorah, A. A. M., \& Fadzil, F. H. B. (2018). The Effect of Board Independence and Board Meeting on Firm Performance: Evidence from Jordan. Journal of Finance and Accounting, 6 (5), 105.

[26] Al-Daoud, K. I., Saidin, S. Z., \& Abidin, S. (2016). Board Meeting and Firm Performance: Evidence from The Amman Stock Exchange. Corporate Board: Role, Duties and Composition, 12 (2), 6-11.

[27] Al-Matari, Y. A., Al-Swidi, A. K., Fadzil, F. H. B. F. H., \& Al-Matari, E. M. (2012). Board of directors, audit committee characteristics and the performance of Saudi Arabia listed companies. International Review of Management and Marketing, 2 (4), 241-251.

[28] Kyereboah-Coleman, A., \& Biekpe, N. (2005). The relationship between board size, board composition CEO duality and firm performance experience from Ghana. Working paper. 